\title{
CASP8-Associated Protein 2
}

National Cancer Institute

\section{Source}

National Cancer Institute. CASP8-Associated Protein 2. NCI Thesaurus. Code C126619.

CASP8-associated protein 2 (1982 aa, $223 \mathrm{kDa}$ ) is encoded by the human CASP8AP2 gene. This protein is involved in the positive regulation of caspase-dependent apoptosis. 